\title{
Short Communication: Genetic structure of Longtail Tuna Thunnus tonggol (Bleeker, 1851) in Java Sea, Indonesia
}

\author{
M. DANIE AL MALIK ${ }^{1, \boldsymbol{v}}$, NI PUTU DIAN PERTIWI ${ }^{1}$, ANDRIANUS SEMBIRING ${ }^{1}$, \\ NI LUH ASTRIA YUSMALINDA ${ }^{1}$, ENEX YUNIARTI NINGSIH ${ }^{1}$, IDA AYU ASTARINII ${ }^{2,3}$ \\ ${ }^{1}$ Biodiversitas Indonesia (BIONESIA). Jl. Tukad Balian No. 121, Denpasar 80226, Bali, Indonesia. Tel: +62-821-47130566, \\ vemail: daniealmalik2@gmail.com. \\ ${ }^{2}$ Departement of Biology, Faculty of Mathematics and Natural Sciences, Universitas Udayana. Jl. Raya Kampus Unud No. 9, Kampus Bukit Jimbaran, \\ Badung 80361, Bali, Indonesia \\ ${ }^{3}$ Program in Environmental Science, Postgraduate Program, Universitas Udayana. Jl. P.B. Sudirman, Denpasar 80232, Bali, Indonesia
}

Manuscript received: 17 March 2020. Revision accepted: 19 July 2020.

\begin{abstract}
Al Malik MD, Pertiwi NPD, Sembiring A, Yusmalinda NLA, Ningsing EY, Astarini IA. 2020. Short Communication: Genetic structure of Longtail Tuna Thunnus tonggol (Bleeker, 1851) in Java Sea, Indonesia. Biodiversitas 21: 3637-3643. Thunnus tonggol (Longtail Tuna) is an economically important fish found in Indonesia waters, however, the information regarding this fish is lacking. Known to be a neritic fish and found in shallow water, Java Sea is one of the ideal habitats for T. tonggol species. Due to high fishing rates activities in Java Sea, a better management plan to ensure the conservation and fisheries sustainability around this area is needed, especially to protect $T$. tonggol population. In order to complete the Indonesian tuna data, we aim to study the diversity and genetic structure of T. tonggol in Java Sea at three different locations; i.e. Semarang, Banjarmasin, and Jakarta. In this study, population genetic methods with the marker of mitochondrial DNA (mtDNA) control region were used in population structure analysis. A total of 115 specimens were collected from the fish market around the area of study locations and amplified using polymerase chain reaction (PCR) and sequenced using Sanger methods. The result showed genetic diversity (Hd) value of 0.99366 , and nucleotide diversity ( $\pi$ ) value of 0.01906. Both of these values indicated high genetic diversity. Population analyses using Analysis of Molecular Variance (AMOVA) showed nonsignificant differences between the three populations of study (mixing population), with the $\Phi_{\mathrm{ST}}$ value of 0,00375 (p-value > 0.05). Based on this result, the fisheries management for T. tonggol in Java Sea needs to be managed as one single population management.
\end{abstract}

Keywords: Connectivity, control region, genetic, fisheries management, Longtail Tuna

\section{INTRODUCTION}

Tuna is one of the important fisheries in the world (Kunal et al. 2013; Benetti et al. 2016) and known as a vital commodity in Indonesia, such as Katsuwonus pelamis (Skipjack Tuna), Thunnus obesus (Bigeye Tuna), and Thunnus albacares (Yellowfin Tuna) (Sunoko and Huang 2014; Suhana et al. 2016). Total production tuna in the world has reached 7.9 million tones, and Indonesia has reached $6.71 \%$ of the total marine capture production, including tuna (FAO 2020a,b). Indonesian local tuna fisheries have been mainly on the small-scale and artisanal fisheries which targeting the neritic tuna (Amri and Satria 2013; Babu and Anrose 2013).

Longtail Tuna (Thunnus tonggol) is a neritic tuna with the same group as Frigate Tuna (Auxis thazard), Kawakawa (Euthynnus affinis), and Skipjack Tuna ( $K$. pelamis) that found mostly near coastal areas (Yesaki 1994; Griffiths et al. 2009; Abdussamad et al. 2012). Longtail Tuna (T. tonggol) has been known as one of the important tuna species for artisanal fisheries (Sadough et al. 2018). This type of tuna usually caught using fishing tools such as gillnets, seine nets, and trolling (Sharma et al. 2012; Restiangsih and Hidayat 2018). The total world production of Longtail Tuna has reached 237. 124 tonnes in 2016 (FAO 2020b), meanwhile in Indian Ocean, including Indonesia, the annual catches reach 116.000 tons (Abdussamad et al. 2012).

Longtail Tuna usually found around Indo-Pacific waters (Sharma et al 2012; Kunal et al 2014; Froese and Pauly 2019). In Indonesia, T. tonggol species is easy to find within the area of Java Sea, including in the Fisheries Management Area-712 (FMA-712) with a total area of $320.000 \mathrm{~km}^{2}$ (Restianingsih and Hidayat 2018); Kep-Men KKP 2016). In their report, it is also mentioned that there is indication of full exploitation of Longtail Tuna population within Java Sea (Restianingsih and Hidayat 2018), which will impact the sustainable fisheries of this species. Furthermore, a study by Sharma et al. (2012), showed that the status of Longtail Tuna in Indo-Pacific has been approaching overfishing category. Although it is reported that Indonesia's Longtail Tuna fisheries have reached about $29 \%$ of all caught in Indian Ocean, and placed at the second top after Iran (42\%), the stock status of Longtail Tuna is uncertain due to the lack of data (Sharma et al. 2012).

Several studies of Longtail Tuna (T. tonggol) has been conducted by taking the total catch and total length on the landing sites (Abdussamad et al. 2012; Restianingsih and 
Hidayat 2018); however, fisheries landing reports may not always represent the actual data, due to the species missidentification thus lead to miss-calculation of the number of catch reports (Pauly and Froese 2012). Therefore, to add more information on this tuna landing reports, genetic studies were conducted. Previous genetic studies to understand the population structure of Longtail Tuna have been conducted in India (Kunal et al. 2014; Kumar et al. 2016) and South China Sea (Willette et al. 2016), but no report on genetic information of Longtail Tuna in Indonesia, particularly in Java Sea. This genetic information can also be used to infer the stock structure of the Longtail Tuna population within Java Sea, and also across Indonesia. Therefore, in this study, we aim to explore the population genetic structure of Longtail Tuna (T. tonggol) in Java Sea using molecular genetic, which is known as a powerful tool to study population. Understanding this population of T. tonggol in Java Sea could become an important data reference to help the conservation manager and policymaker in managing the sustainable fisheries of this species in the area of study (Pertiwi et al. 2017).

\section{MATERIALS AND METHODS}

Samples were collected from fish markets on three different locations including Jakarta $(n=19)$, Semarang
(Central Java) ( $\mathrm{n}=38$ ), and Banjarmasin (South Kalimantan) $(n=58)$ (Figure 1). Samples were collected in the form of fin clips or meat and preserved in $96 \%$ ethanol. Fishing ground location was also confirmed to the local fishermen to ensure the samples were taken on the area of Java Sea (FMA-712). Samples were collected in the period of 2018 until 2019. Samples were taken to laboratory on a cooler box with ice.

This research used a molecular genetic approach using the mitochondrial DNA (mtDNA) of Control Region (Dloop) locus. DNA extraction was done using 10\% Chelex method (Walsh et al. 1991). Mitochondrial (mtDNA) control region fragment was amplified using Polymerase Chain Reaction (PCR), with forward primer (CRK: 5'AGC TCA GCG CCA GAG CGC CGG TCT TGT AAA 3') and reverse primer (CRE: 5' - CCT GAA GTA GGA ACC AGA TG - 3') (Lee et al. 1995).

Table 1. The value of genetic diversity of Longtail Tuna (Thunnus tonggol) based on three populations

\begin{tabular}{lcccc}
\hline Population & Hn & Hd & $\boldsymbol{\pi}$ & N \\
\hline Semarang & 32 & 0,99004 & 0,01932 & 38 \\
Banjarmasin & 49 & 0,99456 & 0,02414 & 58 \\
Jakarta & 15 & 0,97076 & 0,02174 & 19 \\
All & 85 & 0,99268 & 0,02217 & 115 \\
\hline
\end{tabular}

Note: $\mathrm{N}=$ Number of sample, $\mathrm{Hn}=$ Number of Haplotype, $\mathrm{Hd}=$ Haplotype diversity, $\pi=$ Nucleotida diversity

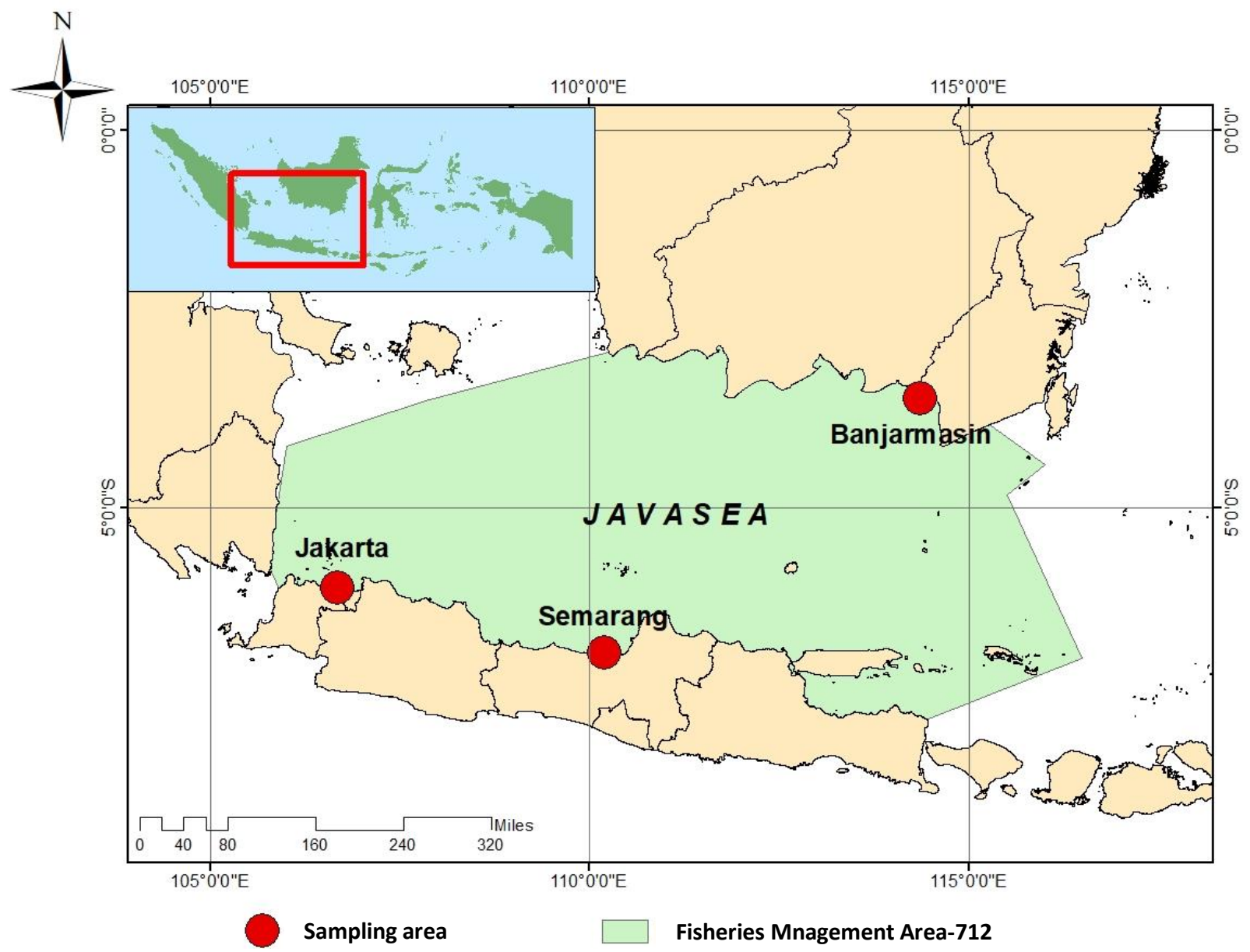

Figure 1. Sampling location of Longtail Tuna (Thunnus tonggol) in Java Sea, Indonesia 
PCR reaction was carried out in the volume of $25 \mu \mathrm{L}$, using $3 \mu \mathrm{L}$ DNA template. PCR reaction and thermocycling profile modified from method in Allen et al. (2017): an initial denaturation of $94{ }^{\circ} \mathrm{C}$ for $15 \mathrm{~s}, 38$ cycles of $94{ }^{\circ} \mathrm{C}$ for $30 \mathrm{~s}, 50{ }^{\circ} \mathrm{C}$ for $30 \mathrm{~s}, 72{ }^{\circ} \mathrm{C}$ for $45 \mathrm{~s}$, with final extension of $72{ }^{\circ} \mathrm{C}$ for $5 \mathrm{~min}$. PCR reaction were included in $25 \mu \mathrm{L}$ reaction volume, with $2.5 \mu \mathrm{L} 10 \mathrm{X}$ PCR Buffer (Applied Biosystems), 2,5 $\mu \mathrm{L} 10 \mathrm{mM}$ dNTPs, $1.25 \mu \mathrm{L}$ of each primer at $10 \mathrm{mM}, 2 \mu \mathrm{L} 25 \mathrm{mM} \mathrm{MgCl}_{2}$ solution, 0.125 $\mu \mathrm{L}$ AmplyTaq $\mathrm{Red}^{\mathrm{TM}}$ (Applied Biosystems), $13 \mu \mathrm{L} \mathrm{ddH}_{2} \mathrm{O}$, and $3 \mu \mathrm{L}$ of DNA (chelex 10\%). PCR product visualized using $1 \%$ of agarose gel stained by Biotium ${ }^{\circledR}$ gel red stain. The PCR product that successfully amplified (Table 1) was sent to DNA Sequencing facility and sequenced using Sanger sequencing methods.

Sequencing editing and alignment was conducted using MEGA6 software (Tamura et al. 2013). The phylogenetic tree was constructed using Bayesian method with MrBayes 3.1 program (Huelsenbeck and Ronguist 2001). The best fit model of molecular evolution for each portioning data was determined using Bayesian Information Criterion (BIC) in jModeltest program (Posada 2008). HKY $+\mathrm{I}+\mathrm{G}$ was selected as the best model. The Markov Chain Monte Carlo (MCMC) analysis with a random starting tree was run for 10 million generations and sampled every 1000 generations. Comparison with the Genbank database (www.ncbi.nlm.nih.gov) using BLAST (Basic Local Alignment Search Tools) was also conducted to accurately identify the sample as $T$. tonggol species. In BLAST result, identity cover value of $99-100 \%$ and query cover value of 98-100\% was used as the cut-off value for the similar species.

Genetic diversity, haplotype distribution, and genetic differentiation analysis from between locations were analyzed using 1000 permutation in each significance tests (p-value<0.05) such as $\mathrm{Ka}^{*}, \mathrm{Kst}^{*}, \mathrm{Z}^{*}, \mathrm{Snn}$, and Fst, which were analyzed using DNASp 6 (Rozas et al. 2017). Meanwhile, population genetic structure $\left(\Phi_{\mathrm{ST}}\right)$ between locations (Semarang, Banjarmasin, and Jakarta) were analyzed using Analysis of Molecular Variance (AMOVA) with 10000 replicates permutation in Arlequin Ver.3.5 (Excoffier and Lischer 2010).AMOVA analysis used the significance level of $5 \%$ (p-value < 0.05). In this analysis, $\Phi_{\text {ST }}$ is used as an analog of Fst that combines genetic distances between sequence data to know the allelic relationship among locations (Excoffier et al. 1992).

\section{RESULTS AND DISCUSSION}

Among all the samples collected, there were differences in the number of samples in each region due to the difficulty in samples collection, which caused by the fishing seasons, the type of artisanal fishing boat used to collect the fish, and also the limitation of areas the Longtail Tuna (Thunnus tonggol) found. Longtail Tuna is known as neritic species of tuna and can be found in the shallow water near coastal areas, therefore this type of tuna species can be found in the area of Java Sea. However, the similar morphological characters this species has with other tuna, has also increased the difficulties in identifying the fish as the correct species, which thus lead to mislabeling it with other tuna species (Pauly and Froese 2012).

Molecular genetic has been known to be a powerful method to help identify species with cryptic morphological characters (Valentini et al. 2009; Bucklin et al. 2011). In this study, we used mitochondrial (mtDNA) control region marker to help identify the correct species of Longtail Tuna (T. tonggol), and used a similar marker to study its population structure. This marker was chosen because of its high polymorphic rate and has been widely used to identify species of tuna and Scombridae family (Menezes et al. 2012; Kumar et al. 2016).

In this study, Chelex method was used in DNA extraction method, because this method has been widely known as a simple, non-hazardous, and rapid genome DNA extraction process compared to other methods (Griese and Linder 1994). Chelex methods have been successfully used to extract good quality of DNA and commonly used methods of DNA extraction for genetic study, especially for commercial tuna such as Thunnus obesus (Pertiwi et al. 2017), Thunnus albacares (Akbar et al. 2014), Auxis thazard, Euthynnus affinis, Katsuwonus pelamis, Rastrelliger kanagurta, and Scomberomorus commerson (Jackson et al. 2014). All of the sequences generated from the samples were deposited in the Genbank database (http://www.ncbi.nlm.nih.gov) with accession no. MT542205-MT542319.

\section{Phylogenetic tree}

Phylogenetic tree result from Bayesian method showed that all the samples from three populations (Jakarta, Semarang, and Banjarmasin) were mixing into one clade (Figure 2). A sequence of Thunnus albacares (yellowfin tuna) (accession no. JN572792.1), and Euthynnus affinis (accession no. JN5655157.1) were used as an outgroup to distinguish the Longtail Tuna samples with other species (Wang et al. 2012).

This study showed a similar pattern as the bigeye tuna (Thunnus obesus) population in Indonesia which indicated one major clade of bigeye population and minor genetic differences between specific locations (Pertiwi et al. 2017). Meanwhile, research conducted by Willette et al. (2016) on Longtail Tuna in several locations in South China Sea, i.e. Indonesia, Vietnam, and Philippines indicated that there was no specific pattern of population difference between locations and population, therefore was considered as a mixing population. Although several tuna species showed a mixing population, there was also an indication that some species showed the signal of genetically differentiated populations, such as the Skipjack study (Katsuwonus pelamis) done by Menezes et al (2012). In this study for the skipjack population of Indian coast showed that there are four different clades of the Skipjack Tuna within the Indian waters.

\section{Genetic diversity and genetic structure}

Genetic diversity result showed haplotype diversity value $(\mathrm{Hd})$ of 0.99268 and nucleotide diversity $(\pi)$ value of 
0.02217. This value of genetic diversity were both considered as high value, compared with the result conducted by Willete et al. (2016) and Kunal et al. (2014). Genetic diversity value of each of the populations is shown in Table 1.

The haplotype distribution also indicated that there was haplotype sharing between population of T. tonggol in Java Sea (Figure 3), with 9 haplotypes shared only between two populations (Jakarta-Banjarmasin, Jakarta-Semarang, Semarang-Banjarmasin), and 1 haplotype was shared among all three populations. The genetic differentiation result indicated that there are no significant differences between locations (p-value < 0.05) (Table 2). The lowest value of Fst was found between Banjarmasin and Semarang (Fst: 0.0021) compared to other locations. Population genetic analysis using Analysis of Molecular Variance (AMOVA) showed the value of $\Phi_{\mathrm{ST}}$ is 0.00328 ( $p$ value $>0.05$ ) (Table 3), which indicated non-significant population structure.

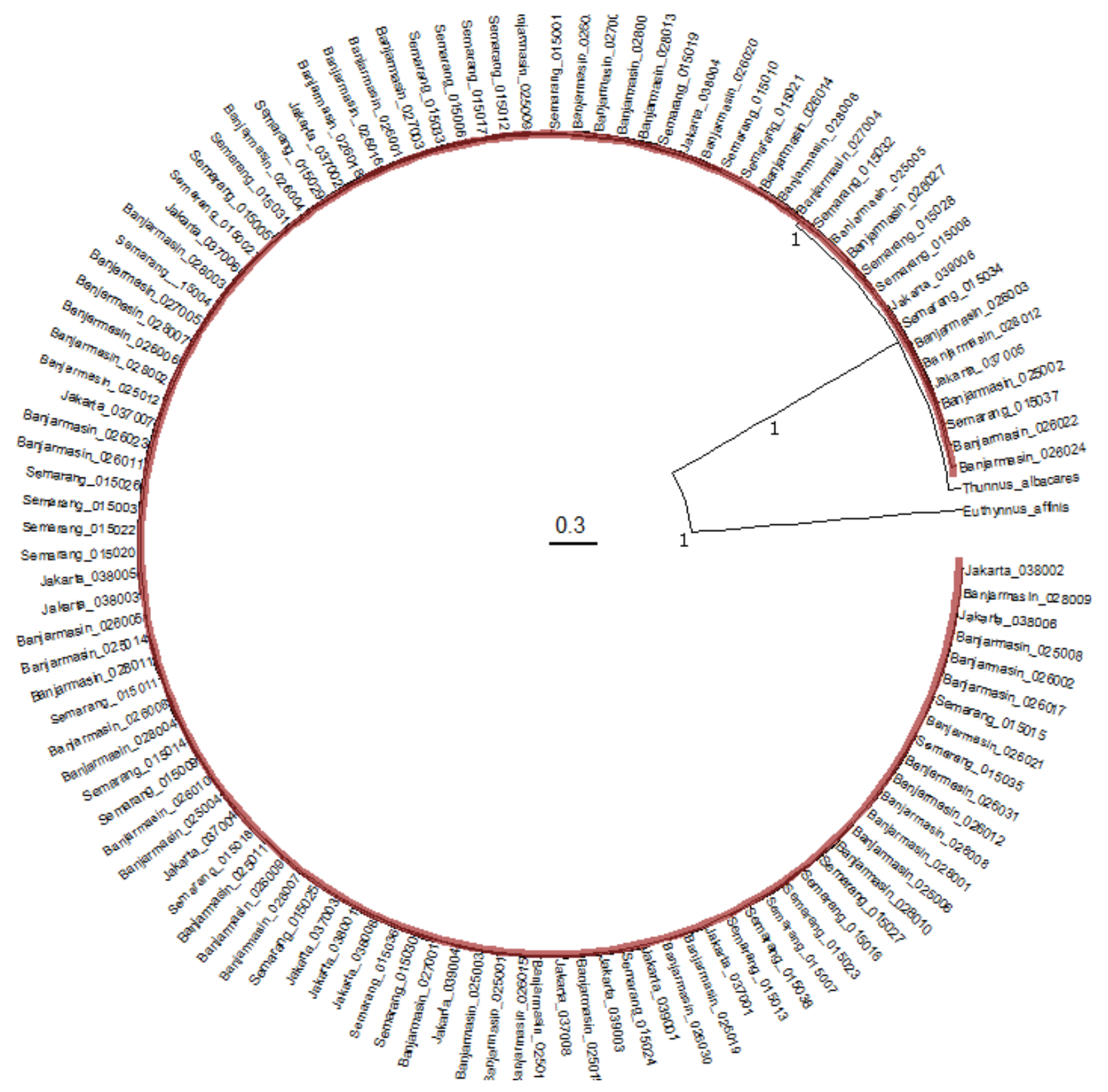

Figure 2. Phylogenetic tree of Thunnus tonggol samples from three locations, analyzed using Bayesian methods. The node number represent posterior probabilities value. Thunnus albacares (accession no. JN572792.1) and Euthynnus affinis (accession no. JN5655157.1) were used as an outgroup. 


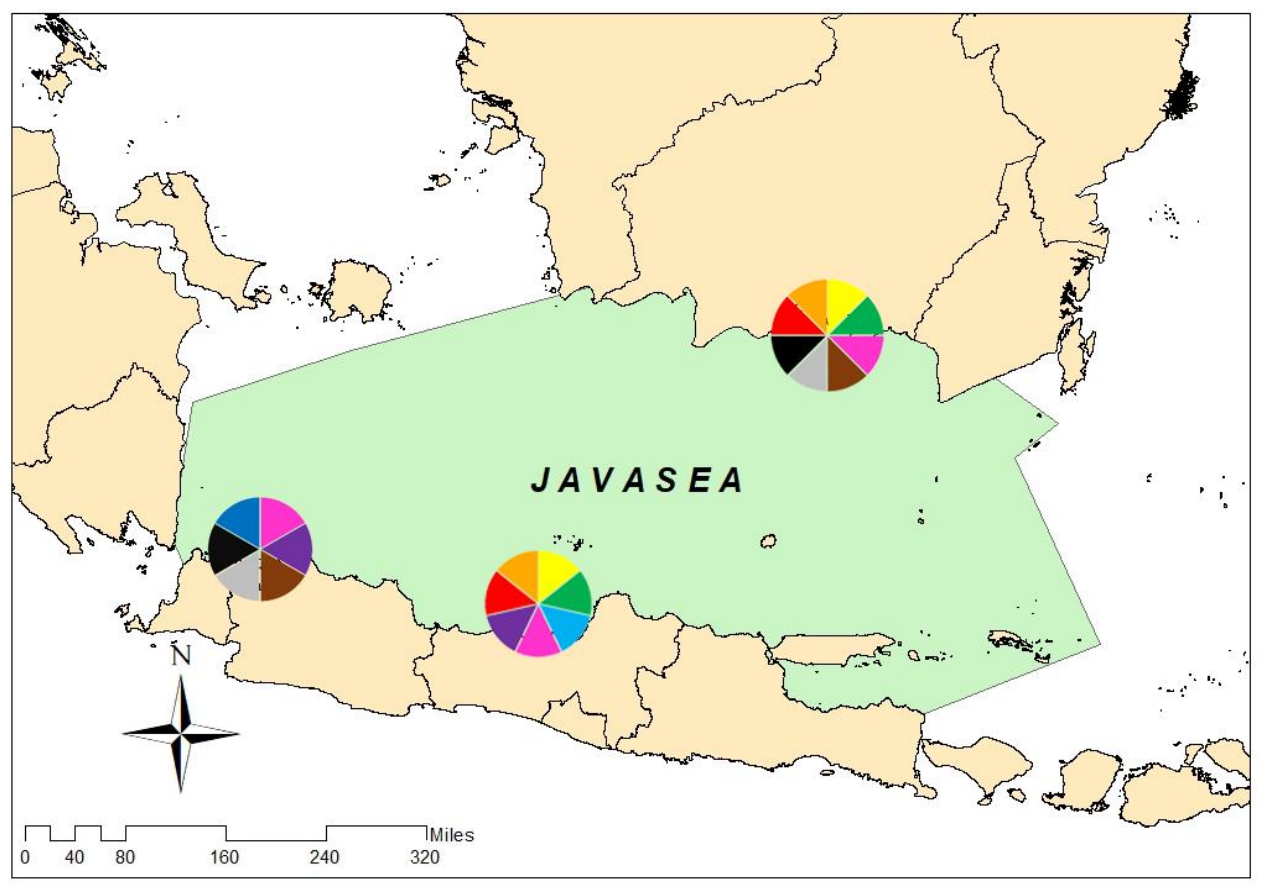

Figure 3. Haplotype distribution of Longtail Tuna (Thunnus tonggol) in Java Sea, Indonesia

Table 2. Genetic differentiation estimates for geographical locations of Longtail Tuna (Thunnus tonggol) in Java Sea, Indonesia

\begin{tabular}{lcccccccc}
\hline \multicolumn{1}{c}{ Location } & Ks* & Kst* & Ks $^{*}$.Kst* P-value & $\mathbf{Z}^{*}$ & P-value & Snn & P-value & Fst \\
\hline Banjarmasin/Jakarta & 8.3865 & 0.0004 & 0.262 & 6.9882 & 0.373 & 0.6732 & 0.167 & 0.0025 \\
Banjarmasin/Semarang & 6.4474 & 0.0010 & 0.311 & 7.4256 & 0.158 & 0.5958 & 0.078 & 0.0021 \\
Jakarta/Semarang & 5.8367 & 0.0039 & 0.162 & 6.3728 & 0.163 & 0.6083 & 0.162 & 0.0056 \\
\hline
\end{tabular}

Table 3. Analysis of Molecular Variance (AMOVA) of Thunnus tonggol in Java Sea, Indonesia

\begin{tabular}{llccc}
\hline Source of variation & DF & Sum of squares & Variance component & Percentage of variation \\
\hline Among population & 2 & 17.359 & $0.03204 \mathrm{Va}$ & 0.33 \\
Within-population & 122 & 1097.815 & $9.80192 \mathrm{Vb}$ & 100.33 \\
Total & 114 & 1115.174 & 9.76987 & \\
ФST & 0.00328 & & & \\
P-value & $0.56554 \pm 0.0070$ & & \\
\hline
\end{tabular}

This result indicated that $T$. tonggol populations in Java Sea were considered as a single group (based on phylogenetic and $\Phi_{\text {ST }}$ result), with high genetic diversity value showed in its high haplotype diversity and nucleotide diversity. High haplotype diversity also indicated by the high number of unique haplotypes between each of population. The result in our study showed similar high haplotype diversity with the study conducted by Kunal et al. (2014) in India that indicated a high genetic diversity value of 0,99 . A similar study using different species of tunas, i.e. Bigeye Tuna (Thunnus obesus) by Pertiwi et al. (2017) in Indonesia, Yellowfin Tuna (Thunnus albacares) by Akbar et al. (2014) in Mollucas sea, and Skipjack Tuna
(Katsuwonus pelamis) by Manezes et al (2012) in Indian Coast, also showed that several species of tuna that has an indication of high genetic diversity.

Population genetic analysis using AMOVA showed that T. tonggol populations in Java Sea were not significantly different and consider as a single population, which showed similar pattern with the result of $T$. tonggol conducted by Kunal et al. (2014) in Coast of India and Willette et al (2016) in South China Sea, although the analysis comparison of Indian and South China Sea population did indicate a distinct clade between those two groups. This resulting study indicated that genetic sharing (gene flow) between population are still happening. The 
migration behavior of tuna may become one of the factors that caused this result (Pecoraro et al. 2015), such as $T$. tonggol that known as an ontogenetic migration species (Griffiths et al. 2007), but not highly migratory (Serdy 2004). The oceanographic condition, such as current flow could also be related to strong gene flow between populations (Saleky et al. 2016). However, geographical distance would not give real effect to the genetic flow on migratory species such as tuna (Akbar and Aris 2018). Furthermore, tuna larval stage can also travel at a great distance of $<50 \mathrm{~km}$ (Green et al. 2014). Although $T$. tonggol is known as neritic tuna and commonly found in shallow water, the characteristic of Java Sea with the maximum depth of $70 \mathrm{~m}$ (Nurhakim et al. 2007) are suitable habitat for T. tonggol

This study can be used as a preliminary result for population stock of $T$. tonggol in Java Sea using genetic approach. Based on the resulting study, integration of policy and fisheries regulation for T. tonggol in Java Sea are needed, especially between each fisheries landing site within Java Sea and FMA-712 (WPP-712), due to the high genetic connectivity between populations of $T$. tonggol in Java Sea. Despite the high genetic diversity of $T$. tonggol in Java Sea, a serious threat in one of its populations can have an impact on the other populations. In the study done by Griffiths et al. (2010), it is showed that T. tonggol has more slow growth rate and live longer than other Thunnus that have the similar size, such as Blackfin Tuna (Thunnus atlanticus), dan Bigeye Tuna (Thunnus obesus). This fact has been indicated that the Longtail Tuna should be protected for its population sustainability.

In one of the $T$. tonggol study in Java Sea, it is mentioned that the conditions of this species in the areas are listed as fully exploited (Restianingsih and Hidayat 2018), which then rise a sustainable fisheries issue because Indonesia and other countries such as Thailand, Malaysia, and Iran are the countries that have a high contribution on the T. tonggol fisheries in the world (Griffiths et al. 2010; Abdussamad et al. 2012; Darvishi et al. 2018). Another study conducted in Southwest Aceh indicated that the condition of $T$. tonggol population in that area indicated a low vulnerability status and high productivity rate, which signifies that the Longtail Tuna population in Southwest Aceh is still in a good level of resource sustainability category (Rahma et al. 2019). Therefore, further research regarding the vulnerability status of $T$. tonggol population in Indonesia is needed to assess the sustainability of this species.

In conclusion, Longtail Tuna (Thunnus tonggol) population within the three different locations in Java Sea (Jakarta, Semarang, and Banjarmasin) showed nonsignificant differences and indicated as a single mixed population. The study would help fisheries managers and conservation managers to uphold management based on location, especially in Java Sea. However, further study is needed to understand the connectivity of Longtail Tuna between all of Indonesia's Fisheries Management Areas (FMA) to protect the sustainability of Longtail Tuna population.

\section{ACKNOWLEDGEMENTS}

We gratefully acknowledge the financial support for this study, from the Partnership for Enhanced Engagement in Research (PEER) Science Program (AID-OAA-A-1100012) funded by the United States Agency for International Development (USAID). We would also like to thanks S.A. Ramadhani, N.I. Setiawan, S. Elvirawati, I.G.A. Diah, and N. Rama for their help in sampling collection and laboratory processes.

\section{REFERENCES}

Abdussamad EM, Koya KP, Ghosh S, Rohit P, Joshi KK, Manojkumar B, Prakasa D, Kemparaju S, Elayath MNK, Dhokia HK, Sebastine M, Bineesh KK. 2012. Fishery, biology, and population characteristics of Longtail Tuna, Thunnus tonggol (Bleeker, 1851) caught along the Indian coast. Indian J Fish 59 (2): 7-16.

Akbar N, Aris M. 2018. Genetic population structure of Yellowfin Tuna (Thunnus albacares) as based data of fish conservation in North Mallucas Sea. Omni-Akuatika 14 (3) 75-85.

Akbar N, Zamani NP, Madduppa HH. 2014. Keragaman genetik ikan tuna sirip kuning (Thunnus albacares) dari dua populasi di Laut Maluku, Indonesia. DEPIK Jurnal Ilmu-Ilmu Perairan, Pesisir dan Perikanan 3 (1): 65-73. [Indonesian]

Alghozali FA, Wijayanti DP, Sabdono A. 2019. Genetic diversity of scalloped hammerhead sharks (Sphyrna lewini) landed in Muncar Fishing Port, Banyuwangi. Biodiversitas 20 (4): 1154-1159.

Allen GR, Erdmann MV, Pertiwi PD. 2017. Description of four new species of damselfishes (Pomacentridae) in the Pomacentrus philippinus complex from the tropical western Pacific Ocean. J Ocean Sci Found 25 (2017): 47-76.

Amri K, Satria F. 2013. Impact of climate anomaly on catch composition of neritic tuna in Sunda Strait. Indon Fish Res J 19 (2): 61-72.

Babu C, Anrose A. 2013. Status of Neritic Tuna Fisheries in India. IOTC2013 WPNT03-09. Bali-Indonesia.

Benetti DD, Partridge GJ, Stieglitz J. 2016. Overview on status and technological advances in tuna aquaculture around the world. In: Advances in Tuna Aquaculture. Academic Press, New York.

Bucklin A, Steinke D, Blanco-Bercial L. 2011. DNA barcoding of marine metazoa. Ann Rev Mar Sci 3 (1): 471-508.

Darvishi M, Paighambari SY, Ghorbani AR, Kaymaram F. 2018. Population assessment and yield per recruit of long tail tuna (Thunnus tonggol) in northern of the Persian Gulf and Oman Sea Sea (Iran, Hormozgan Province). Iranian J Fish Sci 17 (4): 776-789.

Excoffier L, Lischer HE. 2010. Arlequin suite ver 3.5 a new series of programs to perform population genetics analyses under Linux and Windows. Mol Ecol Resour 10 (3): 564-567.

Excoffier L, Smouse PE, Quattro JM. 1992. Analysis of molecular variance inferred from metric distances among DNA haplotypesapplication to human mitochondrial DNA restriction data. Genetics 131 (2): 479-491.

FAO. 2020a. FishStat Thunnus tonggol. FAO Fisheries \& AquacultureAquatic Species. FAO, Rome. www.fao.org/fishery/species/2495/en.

FAO. 2020b. The State of World Fisheries and Aquaculture 2020. Sustainability in action. FAO, Rome.

Froese R, Pauly DE. 2011. FishBase. World Wide Web electronic publication. http://www.fishbase.org

Green AL, Maypa AP, Almany GR, Rhodes KL, Weeks R, Abesamis RA, Gleason MG, Mumby PJ, White AT. 2015. Larval dispersal and movement patterns of coral reef fishes, and implications for marine reserve network design. Biol Rev 90 (4): 1215-1247.

Griese SJ, Linder S. 1994. DNA extraction for PCR: phenol/chloroform vs. Chelex-a comparative study. In: Advances in Forensic Haemogenetics. Springer, Berlin.

Griffiths SP, Fry GC, Manson FJ, Lou DC. 2010. Age and growth of Longtail Tuna (Thunnus tonggol) in tropical and temperate waters of the central Indo-Pacific. ICES J Mar Sci 67 (1): 125-134.

Griffiths SP, Fry GC, Manson FJ, Pillans RD. 2007. Feeding dynamics, consumption rates and daily ration of Longtail Tuna (Thunnus 
tonggol) in Australian waters, with emphasis on the consumption of commercially important prawns. Mar Freshw Res 58 (4): 376-397.

Griffiths SP, Kuhnert PM, Fry GF, Manson FJ. 2009. Temporal and sizerelated variation in the diet, consumption rate, and daily ration of mackerel tuna (Euthynnus affinis) in neritic waters of eastern Australia. ICES J Mar Sci 66 (4): 720-733.

Huelsenbeck J. P. and Ronquist F. 2001. MRBAYES: Bayesian inference of phylogeny. Bioinformatics 17 (8): 754-755.

Jackson AM. Ambariyanto, Erdmann MV, Toha AHA, Stevens LA, Barber PH. 2014. Phylogeography of commercial tuna and mackerel in the Indonesian Archipelago. Bull Mar Sci 90 (1): 471-492.

Kep-Men KKP no.26. 2016. Tentang Rencana Pengelolaan Perikanan Wilayah Perikanan Negara Republik Indonesia 712 [Indonesian]

Kumar G, Kocour M, Kunal SP. 2016. Mitochondrial DNA variation and phylogenetic relationships among five tuna species based on sequencing of D-loop region. Mitochondrial DNA Part A 27 (3): 1976-1980.

Kunal SP, Kumar G, Menezes MR, Meena RM. 2013. Mitochondrial DNA analysis reveals three stocks of yellowfin tuna Thunnus albacares (Bonnaterre, 1788) in Indian waters. Conserv Genet 14 (1) 205-213.

Kunal SP, Kumar G, Menezes MR, Meena RM. 2014. Genetic homogeneity in Longtail Tuna Thunnus tonggol (Bleeker, 1851) from the northwest coast of India inferred from direct sequencing analysis of the mitochondrial DNA D-loop region. Mar Biol Res 10 (7): 738743.

Lee WJ, Conroy J, Howell WH, Kocher TD. 1995. Structure and evolution of teleost mitochondrial control regions. J Mol Evol 41 (1): 54-66.

Menezes MR, Kumar G, Kunal SP. 2012. Population genetic structure of skipjack tuna Katsuwonus pelamis from the Indian coast using sequence analysis of the mitochondrial DNA D-loop region. J Fish Biol 80 (6): 2198-212.

Nei M. 1987. Molecular Evolutionary Genetics. Columbia University Press, New York, USA.

Nurhakim S, Nikijuluw VPH, Nugroho D, Prisantoso BI. 2007. Fisheries management area-fisheries status by management area. Research Center for Capture Fisheries, Jakarta.

Pauly D, Froese R. 2012. Comments on FAO's State of Fisheries and Aquaculture, or 'SOFIA 2010'. Mar Pol 36 (3): 746-752.

Pecoraro C, Babbucci M, Villamor A, Franch R, Papetti C, Leroy B, Ortega-Garcia S, Muir J, Rooker J, Arocha F, Murua H, Zudaire I, Chassot E, Bodin N, Tintin F, Bargelloni L, Cariani H. 2016. Methodological assessment of 2b-RAD genotyping technique for population structure inferences in Yellowfin Tuna (Thunnus albacares). Mar Genom 25: 43-48.

Pertiwi NPD, Nugraha B, Sulistyaningsih RK, Jatmiko R, Sembiring A Mahardini A, Cahyani NKD, Anggoro AW, Madduppa HH, Ambariyanto A, Barber PH, Mahardika GN. 2017. Short Communication: Lack of differentiation within the bigeye tuna population of Indonesia. Biodiversitas 18 (4): 1406-1413.
Posada D. 2008. jModelTest: phylogenetic model averaging. Mol Biol Evol 25 (7): 1253-1256.

Rahmah A, Makhfirah AM, Damora A, Miswar E, Aprilla RM, Sembiring A. 2019. Vulnerability status of Longtail Tuna (Thunnus tonggol) in Southwest Aceh waters, Indonesia. IOP Conf Ser Earth Environ Sci 348 (1): 012116. DOI: 10.1088/1755-1315/348/1/012116

Restianingsih Y H, Hidayat T. 2018. Analisis pertumbuhan dan laju eksploitasi tongkol abu-abu, Thunnus tonggol (Bleeker, 1851) di perairan Laut Jawa. Bawa 10 (2): 111-120.

Rozas J, Ferrer-Mata A, Sánchez-DelBarrio JC, Guirao-Rico S, Librado P, Ramos-Onsins SE, Sánchez-Gracia A. 2017. DnaSP 6: DNA sequence polymorphism analysis of large data sets. Mol Biol Evol 34 (12): 3299-3302.

Sadough N A, Kamrani E, Khanipour A A, Madsen N, Sourinejad I. 2018. Determining gill-net selectivity for Longtail Tuna (Thunnus tonggol Bleeker, 1851) using artisanal fishery data in the Iranian waters of the Oman Sea. Iranian J Fish Sci 19 (1): 510-517.

Saleky D, Setyobudiandi I, Toha HA, Takdir M, Madduppa HH. 2016. Length-weight relationship and population genetics of two marine gastropods species (Turbinidae: Turbo sparverius and Turbo bruneus) in the Bird Seascape Papua, Indonesia. Biodiversitas 17 (1): 2082017.

Serdy A. 2004. One fin, two fins, red fins, bluefins: some problems of nomenclature and taxonomy affecting legal instruments governing tuna and other highly migratory species. Mar Pol 28 (3): 235-247.

Sharma R, Herrera M, Million J. 2012. Indian Ocean neritic tuna stock assessments (Kawakawa and longtail): using surplus production models with effort: An observation error based approach. IOTC Documents IOTC-2012-WPNT02-25 Rev 1 (p. 16).

Suhana, Kusumastanto T, Adrianto L, Fahrudin A. 2016 Tuna industries competitiveness in international market: Case of Indonesia. AACL Bioflux 9 (6): 1251-1259.

Sunoko R, Huang HW. 2014. Indonesia tuna fisheries development and future strategy. Marine Policy 43: 174-183.

Tamura K, Stecher G, Peterson D, Filipski A, Kumar S. 2013. MEGA6: molecular evolutionary genetics analysis version 6.0. Mol Biol Evol 30 (12): 2725-2729.

Valentini A, Pompanon F, Taberlet P. 2009. DNA barcoding for ecologists. Trends Ecol Evol 24 (2): 110-117.

Walsh PS, Metzger DA, Higushi R. 1991. Chelex 100 as a medium for simple extraction of DNA for PCR-based typing from forensic material. BioTechniques 10 (4): 506-513.

Wang Z, Guo Y, Yan Y, Hou G, Fan Y, Feng B, Liu C. 2012. Population genetics of tunas in South China Sea inferred from control regions. J Fish China 36 (2): 191-201.

Willette DA, Santos MD, Leadbitter D. 2016. Longtail Tuna Thunnus tonggol (Bleeker, 2851) shows genetic partitioning across, nut not within, basins of the Indo-Pacific based on mitochondrial DNA. J Appl Ichthyol 32 (2): 312-323.

Yesaki M 1994. A review of the biology and fisheries for Longtail Tuna (Thunnus tonggol) in the Indo-Pacific Region. FAO Fisheries Technical Paper 336 (2): 370-387. 